\title{
Benefit-Cost Analysis of Surra Control in Sumba Timur Nusa Tenggara Timur-Indonesia
}

\author{
Rita Sari Dewi ${ }^{1 *}$ Retno Damajanti S ${ }^{2}$ April H Wardhana ${ }^{3}$ Sri Mulatsih ${ }^{4}$ Chaerul Basri ${ }^{5}$ \\ 1. Veterinary Publict Health, Faculty of Veterinary Medicine, Graduate School of Bogor Agricultural \\ University, Bogor, West Java, Indonesia \\ 2. Department of Animal Disease and Veterinary Public Helath, Faculty of Veterinary Medicine Graduate \\ School of Bogor Agricultural University, Bogor, West Java \\ 3. Department of Parasitology, Indonesian Research Center for Veterinary Sciences, J1. R. E Martadinata \\ No. 30, Kotak Pos 151, Bogor 16124 Indonesia \\ 4. Department of Economic Sciences, Faculty of economics and Management, Graduate School of Bogor \\ Agricultural University, Bogor, West Java, Indonesia, \\ 5. Department of Animal Disease and Veterinary Public Helath, Faculty of Veterinary Medicine Graduate \\ School of Bogor Agricultural University, Bogor, West Java \\ *E-mail of the corresponding author: retnodmail@yahoo.com, ritawibowo29@gmail.com
}

The research is financed by Indonesian agricultural of quarantine agency, The Ministry of Agricultural Indonesia (Sponsoring information)

\begin{abstract}
The Surra control program in East Sumba conducted by the East Sumba government is considered effective in reducing morbidity and mortality, including the use of trypanocidal as curative treatment using diminazene aceturate and preventive treatment using isometamidium chloride. The purpose of this study was to analyze the cost benefits of the Surra control program in East Sumba (2012-2015). The Surra control program requires high costs, including relatively expensive drug prices, a cost-benefit analysis conducted to assess economic feasibility and the results can be a reference for determining further policies in controlling Surra. Economic evaluation using Benefit-cost Analysis uses 3 criteria net present value (NPV), benefit cost ratio (B / C), and internal rate of return (IRR). Our results show that the NPV is 1.488 billion IDR, the B / C ratio is 1.18 and the IRR is $50.1 \%$, this result shows that the control program implemented during 2012 to 2015 in East Sumba is economically profitable and feasible to continue
\end{abstract}

Keywords: Surra, Benefit cost analysis, Benefit cost ratio, Internal rate return, Net present value

DOI: $10.7176 / \mathrm{JNSR} / 9-12-08$

Publication date:June $30^{\text {th }} 2019$

\section{Introduction}

Trypanosoma evansi (T. evansi) is widespread in tropical and subtropical regions of Asia, Africa and South America (Luckins and Dwinger 2004). It causes a disease called Surra. Camels, horses, buffaloes, and highly affected animals, including wildlife, are also vulnerable. This is a disease transmitted through arthropods; some species of hematophagous flies, including Tabanid and Stomoxis, are involved in the mechanical transfer of infection from host to host (OIE, 2012).

Sumba Island is part of the East Nusa Tenggara province and is divided into four districts: West Sumba, Southwest Sumba, Central Sumba, and East Sumba. Until 2009, the island of Sumba was declared a free area of Surra. In 2010, Surra attacked almost all districts (19 out of 22 sub-districts in East Sumba)

In July 2010, the first Surra case occurred in horses and buffaloes in West Sumba, which caused the deaths of 19 of the 48 sick horses and 33 of 67 sick buffaloes. Further investigations by the Denpasar Disease Investigation Center gave positive test results for Surra in 24 of the 65 samples taken (36.9\%). Surra's infection in Sumba occurs when a race horse from Bima-West Nusa Tenggara participates in a race in West Sumba. Another opinion said that the entry of Surra to Sumba Island was also caused by buffalo traffic from Bima because of the cheaper buffalo prices compared to Sumba. Surra's first outbreak in East Sumba occurred in August 2010.

Based on reports from the East Sumba Livestock Service Office, Surra caused deaths in horses and buffaloes and at the peak of the outbreak the mortality rate reached $7.6 \%$ in horses (2010) and $2.7 \%$ in buffaloes (2011). The 
highest morbidity rates reached $11.27 \%$ in horses (2010) and $7.1 \%$ in buffaloes (2011). Morbidity and mortality are higher in horses than buffaloes because horses are more susceptible to Surra (Desquesnes et al., 2013). Infected buffalo often do not show clinical symptoms, and can become a T. evansi reservoir so that it can be a source of transmission (Mastra, 2011)

Various control efforts have been carried out by the East Sumba Government to deal with outbreaks such as the temporary closure of opportunities for horses, buffaloes and cattle from other regions, to make the widest public awareness about the threat of Surra transmission to horses and buffaloes, conducting surveillance and monitoring the presence and transmission in all East Sumba districts, eradicating vector transmitters of Surra disease, treating suspected animals and eradicating as stated in the Regent Decree No: 185/Disnak.524.3/570/ VII / 2010 and Regent Instruction Number: 147 of 2010 in July concerning emergency response against the threat of Surra transmission in East Sumba district in 2010.

The economic losses due to Surra produce significant social impacts for producers, although actual losses are difficult to estimate (Mochabo et al., 2006, Reid, 2002). These losses include death, decreased productivity and intervention costs for chemotherapy (Reid, 2002).

The control program that have been carried out are quite effective, there has been a decrease in morbidity and mortality, especially since the use of diminazene aceturate as curative treatment, and preventive treatment (isometamidium chloride). Tripanocydal control requires high costs because drug prices are relatively expensive. Tripanocydal use in the treatment of trypanosomiasis in Africa costs 4 to $5 \$$ per animal, where farmers are unable to pay (Salifu et al., 2010), while treatment in East Sumba is based on the assumption that 2 times using curative treatment using diminazene aceturate requires 135,000 - 225,000 IDR per head (9.5-15.8 US\$), and for preventive medicine requires 112,000 - 187,500 IDR per cow (7.9-13.2 US\$), with funds from the East Sumba Government. According to Desquesnes et al., 2013, trypanocydal use is quite economically effective, medical costs are commensurate with the effectiveness of the treatment carried out. According to Salah, 2015, the benefit of controlling T. evansi infection in the study area was US $\$ 398,880$.

The overall aims of this research are to find out the benefits of the control program that has been carried out as an evaluation in the subsequent control program.

\section{Materials and Methods}

\subsection{Data collection}

The research was conducted in East Sumba. This study uses primary and secondary data. Primary data was collected from interviews with 30 farmers affected by the Surra outbreak in 2010 - 2013. In total 19 of the 22 districts were affected by the outbreak, and for this data collection, five districts were randomly selected. Secondary data was collected from the East Sumba livestock service report and the Disease Investigation Center (DIC) in Denpasar and Kupang agricultural quarantine station. Data obtained on horses and buffaloes for the period 2010-2015 included the number of animal deaths (mortality), number of sick animals (morbidity), number of animals per infected farm (risk population), and total laboratory samples tested (Table 1 and 2).

\subsection{Economic analysis}

Cost-benefit analysis method were use to economic analysis. There are 3 criteria were using, the Net present value (NPV), Benefit cost ratio (B/C) and Internal rate return (IRR) (Putt et al., 1988; Dijkhuizen and Morris, 1997; and Soekartawi, 2006). With the formulation of criteria for cost-benefit analysis according to Putt et al. (1988) as follows:

1. Net Present Value (NPV) is the difference between the net present value of the benefit and the net present value of the cost, that is formulated in

$\mathrm{n}$

$$
\begin{gathered}
\mathrm{NPV}=\sum_{\mathrm{t}=1}(\mathrm{Bt}-\mathrm{Ct}) /(1+\mathrm{i}) \mathrm{t} \\
\text { 作 }
\end{gathered}
$$

$\mathrm{t}=$ Year

$\mathrm{n}=$ number of years the program took place

$\mathrm{B}=$ number of profits in a given year

$\mathrm{C}=$ total cost for a given year 
$\mathrm{i}=$ the prevailing interest rate

A project can be accepted if the net present value benefit> net present value cost or NPV must be positive.

Table 1. Data used to calculate the direct costs for the outbreak of Surra in East Sumba between 2010 and 2016.

\begin{tabular}{|c|c|c|c|}
\hline Description & Value & Unit & $\begin{array}{l}\text { Source of } \\
\text { Information }\end{array}$ \\
\hline \multicolumn{4}{|l|}{ Mortality costs } \\
\hline Horse price & $5,900,000$ & IDR/animal & Farmer \\
\hline Racing horse price & $20,000,000$ & IDR/animal & Farmer \\
\hline Water buffalo price & $9,000,000$ & IDR/animal & Farmer \\
\hline $\begin{array}{l}\text { Number of dead horses between } \\
2010-2016\end{array}$ & 700 & & $\begin{array}{l}\text { Livestock } \\
\text { services }\end{array}$ \\
\hline Racing horse proportion & 10 & $\%$ & Officer \\
\hline $\begin{array}{l}\text { Number of dead water buffaloes } \\
\text { between } 2010-2016\end{array}$ & 178 & & $\begin{array}{l}\text { Livestock } \\
\text { services }\end{array}$ \\
\hline \multicolumn{4}{|l|}{ Decreased production costs } \\
\hline Horses production loss proportion & 30.6 & $\%$ & $\begin{array}{l}\text { Farmer } \\
\text { questionnaire }\end{array}$ \\
\hline $\begin{array}{l}\text { Water buffaloes production loss } \\
\text { proportion }\end{array}$ & 29.4 & $\%$ & $\begin{array}{l}\text { Farmer via } \\
\text { questionnaire }\end{array}$ \\
\hline $\begin{array}{l}\text { Number of ill horses between } 2010 \text { - } \\
2016\end{array}$ & 565 & & Livestock services \\
\hline $\begin{array}{l}\text { Number of ill water buffaloes } \\
\text { between } 2010-2016\end{array}$ & 221 & & Livestock services \\
\hline \multicolumn{4}{|l|}{ Costs of curative treatment } \\
\hline Price of Diminazenen aceturate & 135,000 & IDR/sachet & Livestock services \\
\hline Price of Isometamidium chloride & 250,000 & IDR/sachet & Livestock services \\
\hline $\begin{array}{l}\text { Number of horses in the infected } \\
\text { region }\end{array}$ & 37,561 & 2010-2016 & Livestock services \\
\hline $\begin{array}{l}\text { Number of water buffaloes in the } \\
\text { infected region }\end{array}$ & 27,191 & $2010-2016$ & Livestock services \\
\hline Treatment officer transport cost & 116,000 & IDR/person & Livestock services \\
\hline Syringe & 2,500 & IDR/animal & Retailer \\
\hline Treatment capacity & 20 & $\begin{array}{l}\text { animal/person/ } \\
\text { day }\end{array}$ & Officer \\
\hline $50 \mathrm{ml}$ distilled water price & 5,000 & IDR/bottle & Retailer \\
\hline Alcohol and cotton price & 200 & IDR/animal & Retailer \\
\hline
\end{tabular}


Table 2. Data used to calculate the indirect costs and control expenditure for the outbreak of Surra in East Sumba between 2010-2016

\begin{tabular}{|c|c|c|c|}
\hline Description & Value & Unit & $\begin{array}{l}\text { Source of } \\
\text { information }\end{array}$ \\
\hline \multicolumn{4}{|l|}{ Costs of preventive treatment } \\
\hline Price of Diminazene aceturate & 250,000 & IDR/sachet & $\begin{array}{l}\text { Livestock } \\
\text { services }\end{array}$ \\
\hline $\begin{array}{l}\text { Number of horses in the infected } \\
\text { region between } 2010-2016\end{array}$ & 37,561 & & $\begin{array}{l}\text { Livestock } \\
\text { services }\end{array}$ \\
\hline $\begin{array}{l}\text { Number of water buffaloes in the } \\
\text { infected region between } 2010-2016\end{array}$ & 27,191 & & $\begin{array}{l}\text { Livestock } \\
\text { services }\end{array}$ \\
\hline Treatment officer transport costs & 116,000 & IDR/person & $\begin{array}{l}\text { Livestock } \\
\text { services }\end{array}$ \\
\hline Syringe & 2,500 & IDR/animal & Retailer \\
\hline Treating capacity & 20 & animal/person & Officer \\
\hline $50 \mathrm{ml}$ Distilled water price & 5,000 & IDR/bottle & Retailer \\
\hline Alcohol and cotton price & 200 & IDR/animal & Retailer \\
\hline \multicolumn{4}{|l|}{ Surveillance and monitoring costs } \\
\hline $\begin{array}{l}\text { DIC officers' transport and } \\
\text { accommodation costs }\end{array}$ & $7,000,000$ & Person/event & $\begin{array}{l}\text { DIC } \\
\text { Denpasar }\end{array}$ \\
\hline Cost of local transportation & 116,000 & Person/event & $\begin{array}{l}\text { Livestock } \\
\text { services }\end{array}$ \\
\hline Sampling capacity & 10 & Sample/person & Officer \\
\hline \multicolumn{4}{|l|}{ Laboratory diagnostic costs } \\
\hline Slide glass price & 750 & IDR/sample & Retailer \\
\hline $\begin{array}{l}\text { Other (ethanol, Giemsa, immersion } \\
\text { oil, tissue) }\end{array}$ & 3,250 & IDR/sample & Retailer \\
\hline $\begin{array}{l}\text { Number of samples taken between } \\
2010-2016\end{array}$ & 72,664 & & $\begin{array}{l}\text { Livestock } \\
\text { services }\end{array}$ \\
\hline \multicolumn{4}{|l|}{ Livestock traffic control costs } \\
\hline Animal health examination costs & 15,000 & IDR/animal & $\begin{array}{l}\text { Livestock } \\
\text { services }\end{array}$ \\
\hline Number of transported horses & 21,988 & & $\begin{array}{l}\text { Livestock } \\
\text { services }\end{array}$ \\
\hline $\begin{array}{l}\text { Number of transported water } \\
\text { buffaloes }\end{array}$ & 12,704 & & $\begin{array}{l}\text { Livestock } \\
\text { services }\end{array}$ \\
\hline \multicolumn{4}{|l|}{ Animal quarantine costs } \\
\hline Number of quarantine horses & 25,261 & & Quarantine \\
\hline $\begin{array}{l}\text { Number of quarantined water } \\
\text { buffaloes }\end{array}$ & 11,493 & & Quarantine \\
\hline Length of quarantine period & 4 & Day/animal & Quarantine \\
\hline Horse feed price & 10,000 & IDR/Animal/day & Quarantine \\
\hline Water buffaloes feed price & 20,000 & IDR/Animal/day & Quarantine \\
\hline Animal care service costs & 40,000 & IDR/animal & Quarantine \\
\hline \multicolumn{4}{|l|}{ Vector control costs } \\
\hline Insecticide price & 50,000 & IDR/Bottle & Retailer \\
\hline Public awareness costs & $20,000,000$ & IDR/year & $\begin{array}{l}\text { Livestock } \\
\text { services }\end{array}$ \\
\hline Extermination costs & 100,000 & IDR/animal & Farmers \\
\hline
\end{tabular}

\section{Benefit Cost Ratio (B/C)}

Benefit cost ratio $(\mathrm{B} / \mathrm{C})$ is the amount of benefits, using the formula:

$$
\mathrm{B} / \mathrm{C}=\left\{\begin{array}{cc}
\mathrm{n} & \mathrm{n} \\
\mathrm{t}=1 & \mathrm{t} \mathrm{t} /(1+\mathrm{i}) \mathrm{t}\} /\left\{\sum \mathrm{Ct} /(1+\mathrm{i}) \mathrm{t}\right\}
\end{array}\right.
$$

Programs are considered to be able to run if the ratio is greater than or equal to 1 . 
3. Internal Rate of Return (IRR) is the discount rate that results in an NPV equal to zero, if the IRR calculation results are greater than the discount factor, it can be said that the investment made is feasible. IRR formula:

$\mathrm{n}$

$$
\mathrm{IRR}=\sum \mathrm{Bt}-\mathrm{Ct} /(1 \mathrm{i}) \mathrm{t}=0
$$

$\mathrm{t}=1$

If the IRR is greater than the prevailing interest rate, then the program can be economically feasible.

Cost-benefit analysis was calculated in the period from 2012 to 2015. The selection of the time period was based on the start of the control program by using diminazene aceturate as a curative drug and isometamidium chloride as a preventive drug. Between 2012-2015 there was a pattern of decreasing mortality and morbidity which could be used as the basis for calculating the benefits component. To obtain a benefit-cost analysis of the Surra control program, identification of the cost and benefit component variables will be identified as the cost-benefit analysis input.

\subsection{Cost of control program of Surra}

The East Sumba Government took several actions to overcome the Surra outbreak, to reduce the case and prevent the Surra from expanding. The main Surra control program is pathogen control (T. evansi) and vector control. The East Sumba government also conducted surveillance and monitoring activities by means of physical inspection of livestock and sampling for laboratory testing of Surra. Transmission of Surra occurs because of livestock traffic, to prevent transmission to other regions or prevent the entry of vulnerable animals need to be inspected at the border area for cattle that are crossed. In order to prevent the spread and overcome the outbreak, the increase of farmers' knowledge about Surra is very important, such as clinical symptoms of disease, susceptible animals, transmission of disease, Surra case reporting system and other knowledge related to Surra.

The Surra outbreak control program in East Sumba consists of curative maintenance costs, preventive maintenance costs, supervision costs, laboratory test, traffic control costs, vector control costs, public awareness costs, and optimization costs. Calculations use data in Tables 4 and 5). Each activity in the program is calculated as program costs

The cost of curative treatment is the administration of drugs for healing purposes for sick animals (per year). Calculated by multiplying the number of sick animals with the cost of curative treatment, namely twice for administering diminazene aceturate and twice for giving isometamidium chloride. The calculation includes the transportation costs of an officer with the capacity to treat 20 animals per day

Preventive treatment costs are treatment for populations at risk to preventing non-infected animals. Calculated by multiplying the number of population at risk (in infected herd) with the cost of preventive treatment with diminazene aceturate three times a year (personal communication with Livestock Service officers in East Sumba). The calculation includes the transportation costs of an officer with the capacity to treat 20 animals per day.

Surveillance costs are the costs related to the surveillance and monitoring of Surra in East Sumba. The surveillance is conducted by The Livestock Services Office of East Sumba and DIC in Denpasar. The costs include the transportation costs of the officer visiting the farm and the collection of blood samples (one officer has the capacity to take 10 blood samples per day).

Laboratory diagnostic costs are the costs of Surra diagnostic tests using stained thin smears.

Livestock traffic control costs are costs related to controlling livestock import and export between regions or islands. Monitoring livestock traffic within Sumba islands was conducted by the East Sumba Livestock Services Office, whilst monitoring import/export traffic between different islands was conducted by the Indonesian Agricultural Quarantine Agency.

Vector control costs are costs related to insecticide sprays to control flies as a vector of Surra. The calculation is based on information given by the farmers in the questionnaire that one bottle of insecticide can be used on 200 animals.

Public awareness costs are the costs related to organizing events to increase public knowledge about Surra.

The extermination costs are the costs related to the extermination of dead livestock by burry and fire the body. The average cost of exterminating one animal, as provided by the farmers in the questionnaire, was 100,000 IDR.

2.4 The benefit of the program 
We broke down the benefits associated with control programs into two categories. First, we estimate the economic impact on livestock mortality. Estimates of mortality are based on data in Pahunga Lodu, one of the sub-districts in East Sumba. Benefits are determined by avoidance losses due to Surra mortality = livestock population $\mathrm{x}$ mortality Surra (\%) x value per animal

Second, we use estimates of morbidity (Pahunga Lodu) and calculate production losses due to this disease, which is around $30.6 \%$ for horses and $29.4 \%$ for buffaloes. Benefits are determined by avoiding loss of production from infected animals (morbidity) $=$ livestock population $\mathrm{x}$ annual Surra morbidity $\mathrm{x}$ value per animal $\mathrm{x}$ percentage loss of production.

\section{Result}

Surra's control strategy in East Sumba consists of several activities, namely as in Table 3. In order to control Surra, the Regent of East Sumba issued Decree of Regent No: 185 / Disnak.524.3 / 570 / VII / 2010 and Instruction of Regent No: 147 of 2010 in July on the emergency response of threat of transmission of infectious animal diseases Surra in East Sumba district in 2010.

Table 3. Cost of the Control Program of Surra in East Sumba (2012-2015)

\begin{tabular}{lrrrrc}
\multicolumn{1}{c}{ Description } & \multicolumn{1}{c}{ (IDR x1000) } \\
\hline Treatment curative & 115,430 & 19,083 & 11,276 & 2,790 & 148,579 \\
\hline Treatment preventive & $2,884,956$ & $3,246,888$ & $1,495,476$ & 448,545 & $8,075,865$ \\
\hline Laboratory test & 24,628 & 45,468 & 51,648 & 76,860 & 198,604 \\
\hline Surveillance & 134,421 & 194,857 & 212,779 & 285,894 & 827,951 \\
\hline Animal control movement & 593,857 & 642,577 & 550,970 & 648,416 & $2,435,820$ \\
\hline Vector control & 4,295 & 4,934 & 2,388 & 761 & 12,378 \\
\hline Public awareness & 20,000 & 20,000 & 20,000 & 20,000 & 80,000 \\
\hline Total & & & & $11,779,197$ \\
\hline
\end{tabular}

The cost of Control Program for Surra Outbreak in East Sumba-NTT-Indonesia (Source: The Livestock Services of East Sumba, DIC of Denpasar, Kupang Animal Quarantine station

*IDR: Indonesia Rupiah

The livestock control program using two types of trypanocidal, Diminazene aceturate as a curative drug and Isometamidium chloride as preventive medicine.

The combination of diminazene aceturate dose of $3.5 \mathrm{mg} / \mathrm{kgBW}, 2$ times an interval of two weeks as curative, and isometamidium chloride dose of $1 \mathrm{mg} / \mathrm{kgBW}$ every 3-4 months as preventive use starting in 2012-2016 (Report of the East Sumba Livestock Services 2012).

Surveillance is part of the control program and In this activity monitoring and monitoring of various outbreak, areas were carried out to treat new cases, monitor old cases and early detection of Surra cases. In this activity blood samples were also taken to detect the disease to be examined using a blood test.

The animal control movement is an important activity in Surra's control, stating that the spread of Surra is caused by the presence of animal traffic, especially from endemic areas. Supervision was carried out by the East Sumba Animal Husbandry Service and the Kupang Class I Agricultural Quarantine Center. Supervision includes protection between regional boundaries

Surra is a vector-transmitted disease that is mainly transmitted by flies Tabanus and Stomoxis. Vector control is carried out by spraying insecticides and animals and the environment of animal pens. The difficulty of this activity is the maintenance of animal release Surra is a vector-borne disease that is mostly transmitted by flies Tabanus and Stomoxis. Vector control using insecticides. Extensive livestock raising systems are released in the pasture so that 
vector control becomes very difficult

In order to increase farmer participation in Surra control, public awareness becomes an integral part of the control program. The activity is in the form of counseling the distribution of brochures and leaflets on the Scriptures and how to control them.

To evaluate the Surra control program that was implemented in 2012-2015, the benefit-cost analysis method was used. The benefit-cost analysis of the Surra control program in Table 4.

Table 4 Component cost of program control Surra diseases

(IDRx1000)

\begin{tabular}{|c|c|c|c|c|c|}
\hline \multirow{2}{*}{$\begin{array}{l}\text { Description } \\
\text { Year }\end{array}$} & \multirow[b]{2}{*}{$\mathbf{0}$} & \multicolumn{4}{|c|}{ Value (IDR*) } \\
\hline & & 1 & 2 & 3 & 4 \\
\hline Cost Component & & 2012 & 2013 & 2014 & 2015 \\
\hline Treatment curative & & 115,430 & 19,083 & 11,276 & 2,790 \\
\hline Treatment prevention & & $2,884,956$ & $3,246,888$ & $1,495,476$ & 448,545 \\
\hline Laboratorium test & & 24,628 & 45,468 & 51,648 & 76,860 \\
\hline Surveillance & & 134,421 & 194,857 & 212,779 & 285,894 \\
\hline Animal control movement & & 593,857 & 642,577 & 550,970 & 648,416 \\
\hline Vector control & & 4,295 & 4,934 & 2,388 & 761 \\
\hline Public awareness & & 20,000 & 20,000 & 20,000 & 20,000 \\
\hline Value of car investment & 250,000 & & & & \\
\hline Value of microscop invesment & 100,000 & & & & \\
\hline Outflow & 350,000 & $3,777,588$ & $4,173,808$ & $2,344,536$ & $1,483,266$ \\
\hline
\end{tabular}

The component that use as cost including investation cost

*IDR: Indonesia Rupiah

The benefits of control programs into two categories, determined by avoidance losses due to Surra mortality and avoiding loss of production from infected animals (morbidity) (Table 5). In calculating benefits including investment salvage value in the last year (investment in a car and 2 microscopes)

Table 5 Benefit component of the program control Surra diseases

(IDRx 1000)

\begin{tabular}{|c|c|c|c|c|c|}
\hline Description & & & Value & & \\
\hline Year & $\mathbf{0}$ & 1 & 2 & 3 & 4 \\
\hline Component of Benefit & & 2012 & 2013 & 2014 & 2015 \\
\hline Horses population (head) & & 33,085 & 29,336 & 30,187 & 32,355 \\
\hline Mortality decline (\%) & & 0 & 3.55 & 0 & 0.13 \\
\hline The benefit of mortality (1) & & 0 & $6,144,425$ & 0 & 248,163 \\
\hline Morbidity decline (\%) & & 0 & 2 & 0.66 & 0.23 \\
\hline The benefit of morbidity (2) & & 0 & $1,059,264$ & 359,697 & 134,351 \\
\hline Population of Buffaloes & & 33,760 & 34,469 & 36,437 & 38,756 \\
\hline Mortality decline (\%) & & 0 & 1.33 & 0 & 0.44 \\
\hline The benefit of mortality (3) & & 0 & $4,125,939$ & 0 & $1,534,738$ \\
\hline Morbidity decline (\%) & & 0 & 0 & 0.44 & 0.13 \\
\hline The benefit of morbidity (4) & & 0 & 0 & 424,214 & 133,312 \\
\hline Salvage value car (5) & & & & & 150,000 \\
\hline
\end{tabular}


Salvage value microscop(6)

60,000

\begin{tabular}{llllll}
\hline Inflow : Total $(1+2+3+4+5+6)$ & 0 & 0 & $11,329,628$ & 783,911 & $2,260,564$ \\
\hline
\end{tabular}

Based on the results in Table 6, the control programs from 2012 to 2015 provide calculations with a total B/C ratio of 1.18 , the total NPV of. 1.488 billion IDR, and IRR $50.1 \%$.

Table 6 Result of benefit cost analysis

(IDRx 1000)

\begin{tabular}{lrrrrr}
\hline Description & \multicolumn{5}{c}{ Value (000) } \\
\hline Year & 0 & 1 & 2 & 3 & 4 \\
\hline Outflow & 350,000 & $3,777,588$ & $4,173,808$ & $2,344,536$ & $1,483,266$ \\
\hline Inflow & 0 & 0 & $11,329,628$ & 783,911 & $2,260,564$ \\
\hline Net inflow & $-350,000$ & $-3,777,588$ & $7,155,820$ & $-1,560,624$ & 777,298 \\
\hline NPV & $1,488,155$ & & & \\
\hline IRR & $50.1 \%$ & & & $1,483,266$ \\
\hline PVC & 350,000 & $3,777,588$ & $4,173,807$ & $2,344,536$ & $2.260,564$ \\
\hline PVB & 0 & 0 & $11,329,628$ & 783,911 & \\
\hline B/C Ratio & 1.18 & & & \\
\hline
\end{tabular}

The result : NPV 1.488 billion IDR, IRR 50.1\% and B/C Ratio 1.18

NPV is the benefit obtained in the program measured at a certain interest rate, $10 \%$ is used in this calculation. $\mathrm{NPV}>0$ or positive then the program is feasible. Net B / C shows how many benefits (benefits) are obtained from the costs incurred. The B / C value of the Surra 1.18 control program indicates that the program is feasible to be implemented. IRR is the ability of a project to generate returns. IRR is the discount rate level that makes the project $\mathrm{NPV}=0$. The IRR calculation results of $50.1 \%$, more from the discounted $10 \%$ so that the program is feasible.

\section{Result}

Economic evaluation of the Surra control program conducted by the East Sumba Animal Husbandry Service with a cost-benefit analysis evaluation method. The control program is considered successful and economical if B / C > 1 and NPV are positive. The cost-benefit analysis of the Surra control program is shown in Table 3.

Cost-benefit analysis can be applied in a variety of situations that are mostly used before the project starts. However, ex-post analysis can also use the cost benefit analysis method. This technique can be used to help answer questions such as whether existing projects can be continued or not (Ramsay et al., 1999)

The Net Present Value is the difference between benefits (PV) and costs (PV). A positive NPV value indicates that a program is profitable. The NPV value of the Surra 2012-2015 control program is positive, which is 1.488 IDR . This figure shows the net benefits of the Surra control program for 4 years.

Net Benefit-Cost Ratio compares the net benefits received with the costs incurred in the control program. The B / $\mathrm{C}$ value shows how much benefits come from costs incurred. The B / C value of the Surra 1.18 control program means that every Rupiah spent in the control program generates benefits of 0.18 IDR. The ratio of $\mathrm{B} / \mathrm{C}$ will be feasible if the value is more than one.

Internal rate of return (IRR) is an assessment criterion in economic analysis to explain whether the control program carried out is capable of producing returns. IRR is the discount factor level when the NPV of cash inflows is equal to the NPV of cash outflows. The calculated IRR is $50.1 \%$, which means that the internal rate of return of the Surra control program is greater than the interest rate used by $10 \%$ so this program is feasible. The Surra control program has provided a $50.1 \%$ profit.

Economic analysis is widely used in evaluating and determining disease control policies (Kusbianto et al., 2012, Probandari, 2007, Wera et al., 2016). The Surra control program that has been carried out by the East Sumba 
Animal Husbandry Service can be considered feasible if it meets several criteria used in the cost-benefit analysis method. Based on the results in Table 8, the control programs carried out from 2012 to 2015 provide a B/C ratio of 1.18 and NPV totaling 1.488 billion IDR and an IRR of 50.1\%, thus the control program implemented in 2012 to 2015 is feasible in terms of economy.

The economic evaluation of the Surra control program that has been carried out by the East Sumba Animal Husbandry Service needs to be done as a basis for consideration of determining Surra's control decisions in the future. Economic evaluation in this study uses a benefit-cost analysis, namely, the control program is considered successful and economical if $\mathrm{B} / \mathrm{C}>1$ and NPV are positive.

Surra is an economically important disease because it causes high mortality, low milk and meat production, low carcass quality, reduced reproductive performance, fertilizer production, and immunosuppressive properties. Financial losses due to Surra are very high (Desquesnes et al., 2013). Because of the impact, T. evansi infection has been assessed according to the criteria of The Animal Health Law (Regulation (EU) No. 2016 (More et al., 2017).

In order to control Surra, the Regent of East Sumba issued Decree of Regent No: 185/Disnak.524.3/570/ VII/2010 and Instruction of Regent No: 147 of 2010 in July on the emergency response of threat of transmission of infectious animal diseases Surra in East Sumba district. According to Salah et al., 2015, the benefit in controlling T. evansi infection in the Somaliland area was US\$398,880. On average US\$720 saved per head per year. The improved trypanosomosis control indicates the potential benefit of about $\$ 700$ million/year in Africa (Kristjanson et al., 1999).

The success of the control program is not only based on treatment strategies but the overall activities in the program. Preventive treatment appears to provide a fairly high portion of the control program compared to curative treatment, preventive treatment to the population at risk treated with isometamidium chloride 3-4 times a year as shown in the Figure 1.

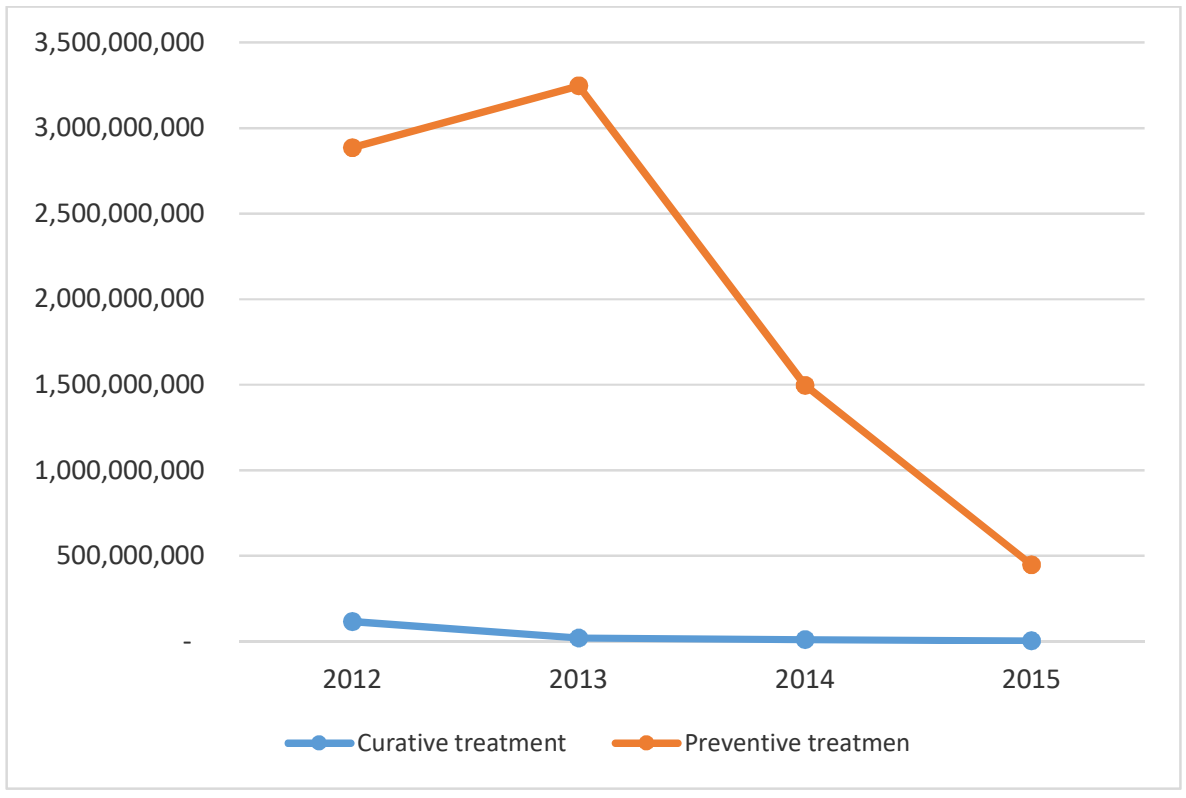

Figure 1. Budget comparation between curative and preventive treatment.

The preventive treatment cost higher than curative treatment cost

In the cost comparison of all control components, treatment for prevention purposes gave the highest percentage $(68 \%)$. It can be seen from Figure 2, based on the cost analysis that a number of activities in control that are still minimal can be increased such as vector control and public awareness activities. Farmers in East Sumba learned about the transmission of Surra through the bite of blood-sucking flies, usually controlling flies using insecticide sprays. Vector control practices are still minimal, only when mass treatment activities or livestock sales. Extensive 
rearing methods with the release of livestock in pastoral fields and semi-permanent conventional cages will increase the risk of abundant vectors in livestock environments. Vector control strategies need to be improved in various ways such as repairing cages to be easily cleaned, and spraying more routine insecticides.

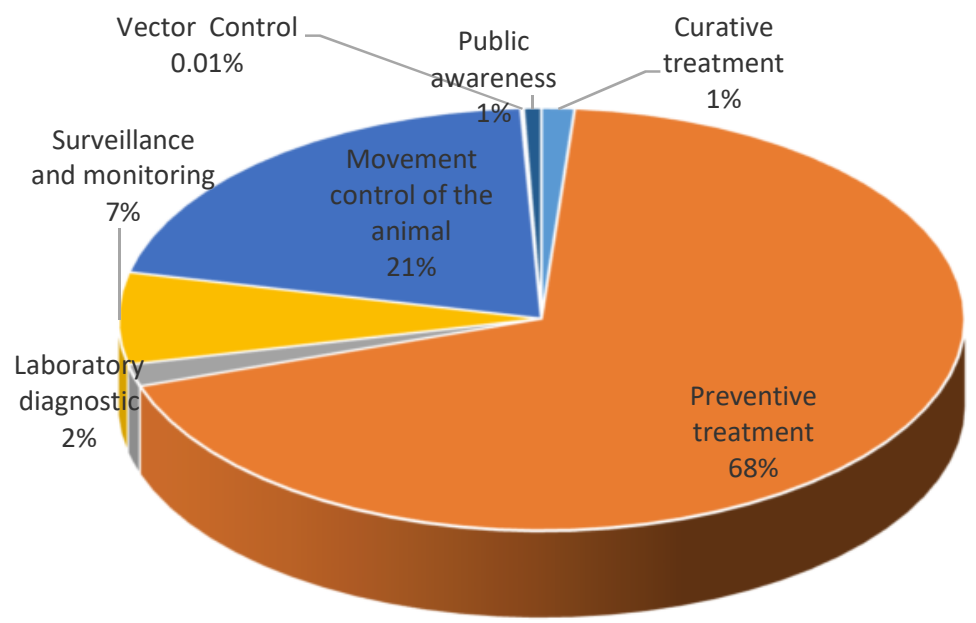

Figure 2. Proportion budget of program control of Surra

Preventive cost takes the biggest proportion (68\%) from control program budget, while the control of vector still very low $(0.01 \%)$

The percentage of laboratory costs is only 2 percent of the total cost with the laboratory methode to detecting Surra at East Sumba using parasitology tests (blood smear). Laboratory testing is one of the important components for surveilance and monitoring, especially in endemic area. Surra has a wide range of hosts and some become reservoirs of disease. The right test method is needed to overcome the condition, such as combination of several test methods (parasitological, serological or molecular) and good sampling techniques. According to Gonzales et al. (2007) and El-Metanawey et al. (2009) in detecting T. evansi at least 2 types of testing are needed.

Some improvements in Surra's control are expected to overcome the Surra case, which until now is still sporadic in East Sumba. Routine and effective surveillance and monitoring systems must be built for the success of Surra's control in the future, the success of the system depends on i) allocation of resources and finance, ii) stakeholder support, iii) commitment from technical staff and surveillance, iv) reporting system effective and good cooperation with farmers. Livestock owners must be very well educated in terms of knowledge about clinical symptoms, biology and the impact of Surra so that they can fully support their monitoring of livestock, always be alert and immediately report to the authorities (Desquesnes et al., 2013).

\section{Conclusion}

The Surra control program in East Sumba conducted from 2012 to 2015 provides a B / C ratio of 1.18, NPV 1.488 billion IDR, and IRR of 50.1\%. The control program implemented during 2012 to 2015 in East Sumba is economically profitable so it is feasible to continue

\section{References}

Davison HC, Thrusfield M, Muharsini S, Husein A, Partoutomo S, Rae PF, Masaki R, Luckins AG. (1999). Evaluation of antigen detection and antibody detection tests for Trypanosoma evansi infections of Buffaloes in Indonesia. Epidemiol. Infect. 123(1),149-155.

Claes F, Radwanskw M, Urakawa T, Majiwa PAO, Goddeeris B, Buscher P. (2004). Variable surface glycoprotein 
Ro Tat 1.2 PCR as a specific diagnostic tool for detection of T. evansi infection. Kinetoplastid Biology and Diseases. 3(3),1-6.

Jaiswal AK, Sudan V, Neha, Verma K. (2015). Insight into Trypanosomiasis in animals: Various approaches for its diagnosis, treatment, and control: a review. Asian J. Anim. Sci. 9(5),172-186.

Salifu AW, Brempong SA, Alhassan R. (2010). Benefit-cost analysis and socio-economic considerations of trypanosomiasis control and treatment in Northern Ghana. African J.Agr. Research. 5(17), 2281-2288.

Desquesnes M, Dargantes A, Lai D, Lun ZR, Holzmuller P, Jittapalapong S. (2013). Trypanosoma evansi and Surra: a review and perspectives on transmission, epidemiology, and control, impact, and zoonotic aspects. BioMed Research International.

Kristjanson PM, Swallow BM, Rowlands GJ, Kruska RI, De Leeuw PN. (1999). Measuring the cost of African animal trypanosomosis, the potential benefits of control and returns to research. Agricultural System. 59,79-98.

Luckins AG, Dwinger RH. (2004). Non-tsetse transmitted animal Trypanosomiasis In The Trypanosomiases. CABI publishing. 269-282.

Mastra IK. (2011). Seroprevalensi Trypanosomiasis di Pulau Sumbawa. Propinsi Nusa Tenggara Barat. Buletin Veteriner BBVet Denpasar XXIII,131-138.

More S, Botner A, Butterworth A, Calistri P, Depner K, Edwards S, Garin-Bastuji B, Good M, Schimidt CG, Michel V, Miranda MA, Nielsen SS, Raj M, Sihvonen L, Spoolder H, Stegeman JA, Thulke H, Velarde A, Willeberg P, Winckler C, Baldinelli F, Broglia A, Cardiani D, Beck BB, Kohnle L, Morgado J, Bicout D. (2017). Assessment of listing and categorization of animal disease within the framework of the Animal Health Law (Regulation (EU) No 2016/429): Trypanosoma evansi infections (including Surra). Efsa Journal. 15(7), 4892

Muieed MA, Chaudhary ZI, Shakoori AR. (2010). Comparative studies on the sensitivity of polymerase chain reaction (PCR) and microscopic examination for the detection of Trypanosoma evansi in horses. Turkish Journal of Veterinary and Animal Sciences. 34,507:512.

[OIE] Organization Internationale de Epizootic. (2012). Trypanosoma evansi infection.OIE Terrestrial Manual Chapter 2.1.17. doi: 10.1080/01652176.1986.9694049.

Partoutomo S, Soleh M, Politedy F, Day A, Wilson AJ, Copeman DB. (1995). Studi patogenesis Trypanosoma evansi pada kerbau, sapi Friesian Holstein dan sapi peranakan ongole. Jurnal Ilmu Ternak dan Veteriner. 1,41-48.

Payne RC, Sukamto IP, Djauhari D, Partoutomo S, Jone TW, Luckin AJ, Boid R. (1991). Trypanosoma evansi infection in cattle, buffalo, and horses in Indonesia. Veterinary Pathology. 38,253-256.

Ramsay GC, Philip P, Riethmuller P. (1999). The economic implications of animal diseases and disease control at the national level. Revue Scientifique et Technique (International Office of Epizootic). 18(2),343-356.

Reid SA. (2002). Trypanosoma evansi control and containment in Australia. Review Trends in Parasitology. 18,209-224.

Rushton J, Thornton PK, Otte MJ. (1999). Methods of economic impact assessment. Revue Scientifique et Technique International Office of Epizootics. 18,315-342.

Sahin A, Asencio C, Izotte J, Pillay D, Coustou V, Karembe H, Baltz T. (2014). The susceptibility of Trypanosoma congolense and Trypanosoma brucei to isometamidium chloride and its synthetic impurities. Veterinary Parasitology. 203 ,270-275.

Salah AA, Robertson I, Mohamed A. (2015). Estimating the economic impact of Trypanosoma evansi infection on the production of camel herds in Somaliland. Tropical Animal Health and Production. 47:707-714 